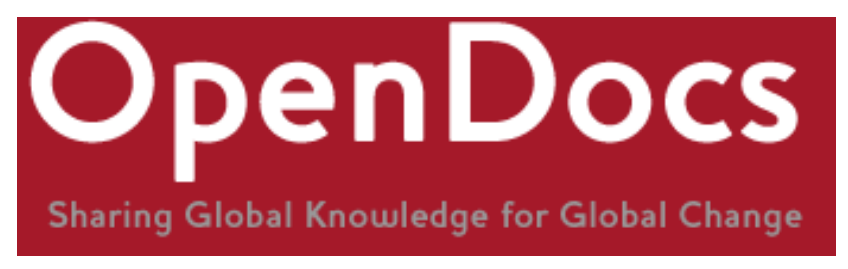

Title: Fiscal Policy, State Building and Economic Development

Citation: Addison, T; Niño-Zarazúa, M. and Pirttiä, J. (2018) Special Issue: Fiscal Policy, State Building and Economic Development, Journal of International Development, 30:3, 161172

Official URL: https://doi.org/10.1002/iid.3355

More details/abstract: This article presents a synopsis of the contextual conditions, factors and challenges under which the recent evolution of tax systems has taken place, as an introduction to this United Nations University-World Institute for Development Economics Research Special Issue. The article, as the studies in this collection, gives especial emphasis to the role natural endowments, political economy, social structure and history, and the interplay between politics and tax revenues. These are relevant issues, considering that the Millennium Development Goals and now the Sustainable Development Goals have placed fiscal policy, and tax policy and revenue mobilisation in particular, at the centre of national and international development efforts. Delivering on the Sustainable Development Goals will require a level of state revenue mobilisation capacity in many ways unprecedented in the history of development policy.

Version of record: ( 2018 UNU-WIDER. Journal of International Development published by John Wiley \& Sons, Ltd. This is an open access article under the terms of the Creative Commons Attribution-NonCommercial-ShareAlike License, which permits use and distribution in any medium, provided the original work is properly cited, the use is non-commercial and the content is offered under identical terms.

This is a download from OpenDocs at the Institute of Development Studies

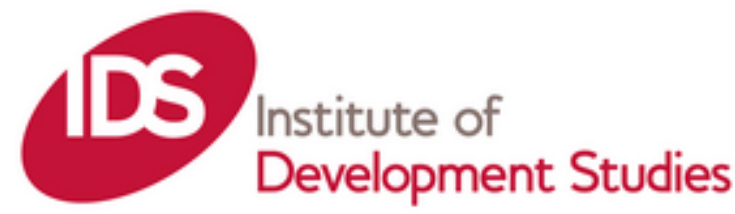




\title{
FISCAL POLICY, STATE BUILDING AND ECONOMIC DEVELOPMENT
}

\author{
TONY ADDISON ${ }^{1}$, MIGUEL NIÑO-ZARAZÚA ${ }^{1 *}$ (iD and JUKKA PIRTTILÄ ${ }^{1,2}$ \\ ${ }^{1} U N U-W I D E R$, Helsinki, Finland \\ ${ }^{2}$ University of Tampere, Tampere, Finland
}

\begin{abstract}
This article presents a synopsis of the contextual conditions, factors and challenges under which the recent evolution of tax systems has taken place, as an introduction to this United Nations University-World Institute for Development Economics Research Special Issue. The article, as the studies in this collection, gives especial emphasis to the role natural endowments, political economy, social structure and history, and the interplay between politics and tax revenues. These are relevant issues, considering that the Millennium Development Goals and now the Sustainable Development Goals have placed fiscal policy, and tax policy and revenue mobilisation in particular, at the centre of national and international development efforts. Delivering on the Sustainable Development Goals will require a level of state revenue mobilisation capacity in many ways unprecedented in the history of development policy. (c) 2018 UNU-WIDER. Journal of International Development published by John Wiley \& Sons, Ltd.
\end{abstract}

Keywords: tax policy; economic development; developing countries

JEL Classification: H23; H26; N40; N50; O23; P16

\section{INTRODUCTION}

The last two decades or so have seen a renewed interest in the role of fiscal policy in stimulating economic growth, diversifying economies and reducing poverty. For some countries, reducing high levels of social inequality is also on the agenda, especially when the pattern of growth is quite narrow in its direct benefits via employment and livelihoods, which is largely the case in economies with substantial extractives sectors. This necessitates more reliance on the fiscal system as a means towards achieving inclusive growth', whereby effective institutions for revenue policy and collection as well as for public expenditure management are vital to redistributing resource rents (Daniel, Keen, Świstak, \& Thuronyi, 2017; Mosley, 2017). This broader range of goals for fiscal policy marks a shift from its narrow focus on macro-economic stabilisation in the 1980s and early

*Correspondence to: UNU-WIDER, Helsinki, Finland.
E-mail: miguel@ wider.unu.edu

(C) 2018 UNU-WIDER. Journal of International Development published by John Wiley \& Sons, Ltd. This is an open access article under the terms of the Creative Commons Attribution-NonCommercial-ShareAlike License, which permits use and distribution in any medium, provided the original work is properly cited, the use is non-commercial and the content is offered under identical terms. 
1990s, when a combination of terms of trade shocks and institutional weaknesses in public expenditure management and revenue mobilisation led to often desperate fiscal crises and painful 'structural adjustment' (Addison, 2015; Stewart, 1996).

More 'fiscal space' started to become available from the 1990s onwards as debt relief accelerated, especially through the successive Heavily Indebted Poor Countries (HIPC) initiatives (Addison, Hansen, \& Tarp, 2004). Additionally, a renewal of economic growth started to generate more tax revenue, which was amplified as tax reform, including a major reconstruction of tax-collection systems, began to raise revenue to gross domestic product (GDP) ratios in many, but not all, countries (see Figures 1 and 2). This, together with the hard grind of public expenditure reform—still, however, ongoing — created more fiscal space to start addressing a broader range of policy goals in addition to just that of macro-economic stability.

The Millennium Development Goals and now the Sustainable Development Goals (SDGs) have placed fiscal policy, including domestic resource mobilisation, at the centre of national and international development efforts (United Nations, 2015). The SDGs imply large and sustained public expenditures to continue the success of the Millennium Development Goals in improving human development indicators, especially in the areas of access to basic health care and primary education, with a particular emphasis on ending gender discrimination (Addison, Niño-Zarazúa, \& Tarp, 2015; Grown, Addison, \& Tarp, 2016).

Moreover, the SDGs also imply large-scale public expenditures to support improved livelihoods for poor people-via better infrastructure access, more research into smallholder crops, etc.-not only to end poverty but also to help close gaps in the distribution of wealth and income by gender, region, and income-category. Finally, climate change will impose large fiscal burdens as the frequency and intensity of extreme weather events increase, requiring more public expenditure on disaster relief and, in some cases, reducing the tax base through economic damage consequent on increased drought and flooding. Climate adaption and mitigation, as well as the achievement of other environmental goals such as improved urban air quality and reduced water pollution, are additional substantial demands on the public purse.

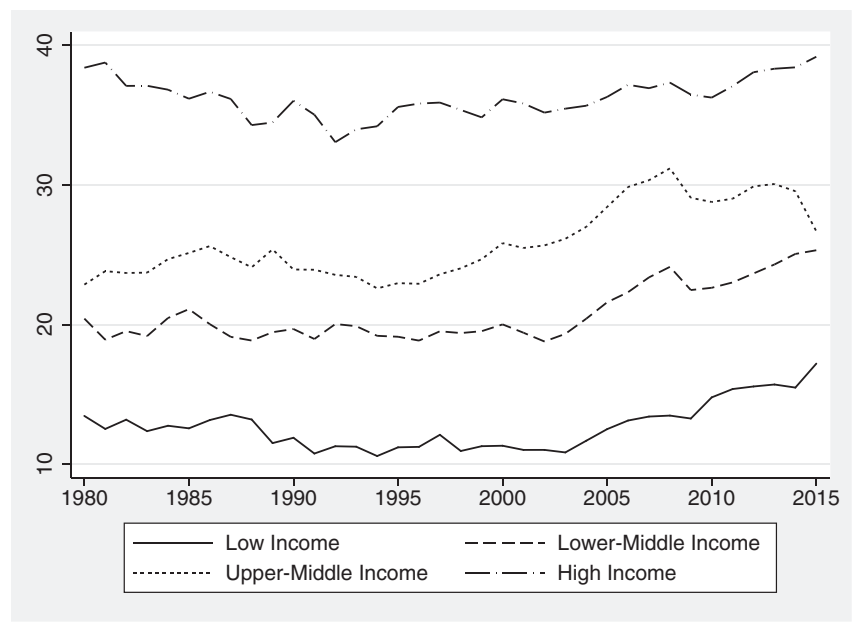

Figure 1. Total tax revenue including social security contributions by income groups Source: Authors' own calculations, based on GRD data. 


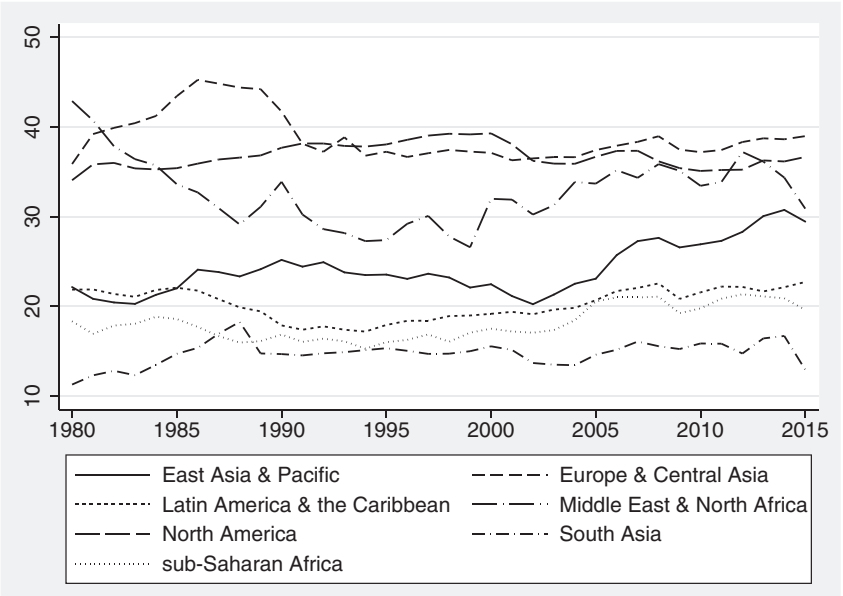

Figure 2. Total tax revenue including social security contributions by regions Source: Authors' own calculations, based on GRD data.

Domestic resource mobilisation has also been encouraged by aid donor countries, as the growth in official development assistance has been less than expected ('aid fatigue'). OECD-DAC donors came under pressure with the financial crisis of 2009-2010, and the resulting recession, leading to a slowdown in the growth of real aid volumes, with large cuts to bilateral aid budgets in some cases. Donors have placed greater emphasis on the 'social contract' between states and citizens (Mosley, 2014). This has strong fiscal dimensions, as the willingness of citizens to pay or evade taxes is motivated in part by whether they perceive the burden of taxation to be fair as well as the distribution of the spending it finances, including the spatial pattern of public spending within countries which is often correlated with, and a determinant of, local poverty and human development outcomes.

Delivering on the SDGs requires a level of state capacity that is in many ways unprecedented in the history of development policy. Local and central government, and their supporting administrations, must prioritize spending in the context of many competing demands and trade-offs, and build effective mechanisms to manage and spend public money. Some of the increased revenues generated by better tax systems must be spent on the state itself. This is especially so in the group of fragile states, including those where rebuilding and reforming the fiscal system is vital to achieving peace and stability-as well as achieving recoveries that are inclusive in their benefits (Addison, Chowdhury, \& Murshed, 2004; Gupta et al., 2009).

In sum, the role of fiscal policy in development has broadened over time, and tax policy and revenue mobilisation have moved up the policy agenda. Accordingly, there is now a renewed interest in the economics literature over fiscal policy in relation to economic growth, poverty reduction, and income inequality (Alesina \& Ardagna, 2010; Muinelo-Gallo \& Roca-Sagalés, 2013; 2014; Woo, 2011). Notably, the economics literature on tax policy in low-income countries (LICs) and middle-income countries (MICs) is now closer to the literature on tax policy in advanced economies. This includes a greater emphasis on the quality of tax institutions, including benchmarking progress in tax administrations and issues around compliance and how this can be best improved without damaging real economic activity (Keen \& Slemrod, 2017). 
Despite the relatively extensive literature that explores the relationship between tax policy and developmental concerns in the domains of inter alia governance (Alesina, Campante, \& Tabellini, 2008; Baldacci, Hillman, \& Kojo, 2004; Marjit, Mukherjee, \& Kolmar, 2006; Moore, 2007), democracy (Ganghof \& Genschel, 2008; Herb, 2005; Mutascu, 2011; Persson \& Tabellini, 1994), growth (Bleaney, Gemmell, \& Kneller, 2001; Devereux \& Wen, 1998; Jaimovich \& Rebelo, 2017; Scully, 2003; Yakita, 2003) and how the tax structure of nations impact efficiency and equity considerations (Atkinson \& Stiglitz, 1972, 1976; Deaton, 1977; Feldstein, 1972; Gordon, 1983; Shavell, 1981), and generate incentives for tax evasion and avoidance (Emmens \& Kephart, 2005; Sandmo, 2005; Slemrod, 2007; Slemrod \& Yitzhaki, 2002), there is also a general recognition that significant knowledge gaps still exist in better understanding the underlying structural, institutional and normative factors that have permitted (or limited) the building of effective states as conditio sine qua non for economic and social progress (Acemoglu \& Robinson, 2012; Besley \& Persson, 2011).

\section{DATA}

To a very large extent, data limitations have hampered prospects for expanding and deepening the research base on these vital policy questions. The most widely used cross-country database on government revenues has been the International Monetary Fund (IMF) Government Finance Statistics (GFS). ${ }^{1}$ However, the IMF GFS has so far offered a limited and truncated sample of developing countries, often with inconsistencies across time and space (Prichard, 2016).

In recent years, a few datasets have been constructed to improve the limited samples in the IMF GFS data (Baskaran \& Bigsten, 2013; Benedek, Crivelli, Gupta, \& Muthoora, 2014; Haber \& Menaldo, 2011); however, the proliferation of multiple datasets that rely on dissimilar methodologies, and which often poorly document adjustments to data, has made international comparisons very difficult.

More recently, the International Centre for Tax and Development (ICTD) and the United Nations University-World Institute for Development Economics Research (UNUWIDER) initiated a collaboration on taxation, revenue mobilisation and development with the objective of encouraging the creation and distribution of more accurate data on government revenues as well as its analysis for policy. This initiative builds upon the previous work initiated by ICTD in developing the Government Revenue Database (GRD), which harmonizes data from several major international databases including (i) the IMF GFS; (ii) the OECD Tax Statistics dataset ${ }^{2}$; (iii) the Revenue Statistics in Latin America and the Caribbean dataset, ${ }^{3}$ which is constructed by the OECD, the United Nations Economic Commission for Latin America and the Caribbean, the Inter-American Centre of Tax Administrators and the Inter-American Development Bank; (iv) the World Bank's World Development Indicators; and (v) the African Economic Outlook and data compiled from all available IMF Article IV reports.

The work on the GRD dataset has resulted in a more complete and accurate international GRD, and one that will be regularly updated by UNU-WIDER, and made openly and

\footnotetext{
${ }^{1}$ For further details, see: http://www.imf.org/external/pubs/ft/gfs/manual/gfs.htm

${ }^{2}$ For further details, see https://stats.oecd.org/Index.aspx?DataSetCode=REV

${ }^{3}$ For further detuiahttp://www.oecd.org/ctp/revenue-statistics-in-latin-america-and-the-caribbean-24104736.htm
} 
widely available through the UNU-WIDER website: https://www.wider.unu.edu/project/ government-revenue-database. An important aim of this collaboration is to encourage the use of the GRD in research on the role of taxation and revenue mobilisation in achieving inclusive and sustainable economic and social development. This Special Issue of The Journal of International Development aims to contribute to this goal.

Revenue mobilisation and tax policy constitute a critical set of development issues, as discussed earlier in this introduction to the Special Issue. Over the past four decades, the evolution of tax systems, their composition and contribution to government revenues has been marked by a distinct variation across world regions and country income groups. Broadly, LICs and MICs in the sub-Saharan African, Latin American and especially Asian regions have exhibited a limited revenue capacity-measured by total tax revenue as a percentage of GDP - relative to high income countries in North America and Europe, although the capacity of the former groups of countries has gradually started to rise over the past decade (see Figures 1 and 2). This clearly is positive news, although the level of tax revenues in the poorest countries remains insufficient to fully finance developmental spending, leaving aid with an important and continuing role.

An important aspect of these recent trends is the composition of tax revenues. As shown in Figure 3, the share of direct taxes - that is, income taxes on individuals and corporations - has been somewhat stable among LICs and MICs, although the contribution of direct taxes to total tax receipts has slightly increased since the first decade of the 2000s. This suggests that there is, in principle, considerable scope for a broader personal income tax base across the developing world, which in turn makes it possible to introduce more progressivity into the income tax system. This task is, however, contingent upon a myriad of political economy factors, including incumbents' incentives and preferences for redistribution, in what are increasingly competitive political systems (Alesina \& Giuliano, 2011; Caselli \& Cunningham, 2009; Dhami, 2003).

The main trend in the tax composition has been the increase in the share of tax revenue that is raised by consumption taxes (Figure 4). The main driver here has been a widespread

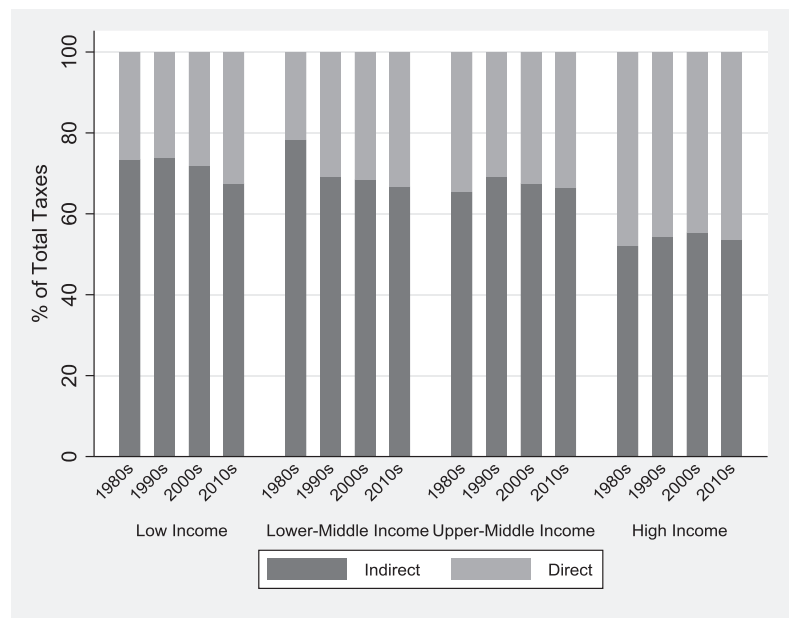

Figure 3. The tax mix (shares of direct vs indirect taxes out of total revenue) by income groups Source: Authors' own calculations, based on GRD data. 


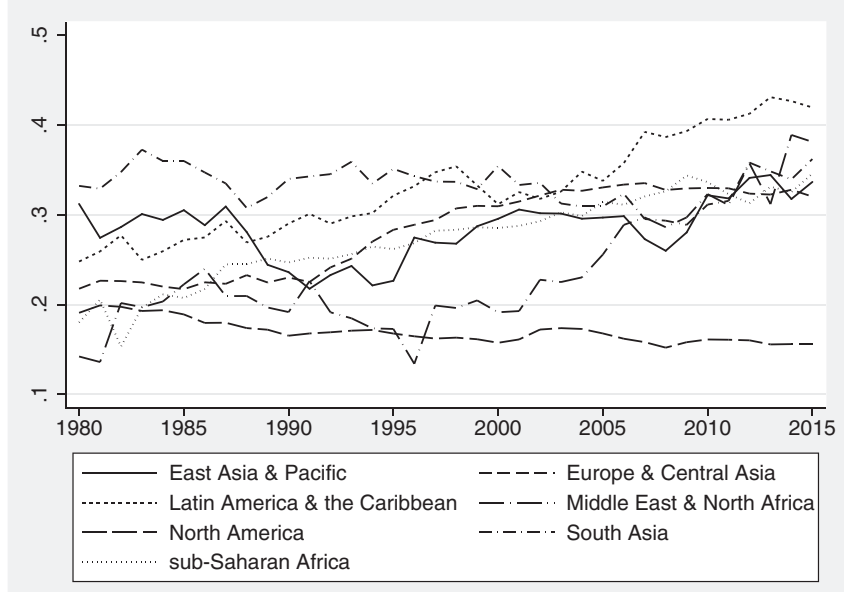

Figure 4. Share of domestic consumption taxes (the VAT and excises) by regions Source: Authors' own calculations, based on GRD data.

adoption of the value-added tax (VAT), which has gradually replaced trade tax revenue as countries began to liberalize their trade from the 1980s onwards. ${ }^{4}$

\section{THIS COLLECTION}

The economic literature on tax and revenue mobilisation in developing countries has predominantly focused on identifying common problems to tax collection, studying the impacts of a given tax policy, and studying the trade-offs between efficiency and equity in a general equilibrium framework.

Questions regarding the link between the tax structure and economic growth and economic performance, especially in the context of developing countries, have not yet been sufficiently addressed. Indeed, important questions in the domains of economic performance, political economy and political dynamics remain open: (i) Why nations, even at similar levels of economic converge exhibit huge variation in their fiscal capacity? (ii) What policy strategies (and conditions) have recently facilitated the revenue capacity and redistribution efforts of developing regions? (iii) What structural and political economy factors have shaped the capacity of states to mobilize tax revenues that ultimately help build welfare institutions? These are major questions. Fiscal capacity is an essential ingredient for economic growth, redistribution and the provision of public goods.

On 14-15 March 2016, UNU-WIDER together with ICTD organized a 'Symposium on Taxation and Revenue Mobilization in Developing Countries' with the aim of addressing these key questions. The papers that constitute this Special Issue are the result of this joint effort and contribute to the literature of tax policy, its macroeconomic aspects and its political economy dimensions.

The studies by Kyle McNabb, Alex Cobham and Petr Janský, and Martin Hearson focus on a first set of questions, linking taxation and the tax structure of countries with growth

\footnotetext{
${ }^{4}$ For a recent analysis on the impacts of the adoption of the VAT on tax revenues and inequality see Alavuotunki et al. (2017). 
and economic performance, tax evasion and avoidance and tax treaties, respectively, whereas the study by Bruno Martorano addresses the second set of questions that are related to issues of taxation and redistribution by focusing on Latin America, a region that has experienced reductions in income inequality over the past 15 years.

More specifically, the paper by McNabb (2018) considers the effects of revenue neutral changes in tax structures on economic growth, using a panel of approximately one hundred developing and developed countries. According to his results, one of the most drastic changes in the tax structure- the move from trade to domestic consumption taxes-has had a positive impact on growth only in lower-middle income countries. He also finds that revenue neutral increases in personal income taxes or social contributions are found to be harmful for long-run per capita GDP growth rates. The study highlights the importance of heterogeneity in the relationship between tax structures and growth, which also means that policy statements about growth-conducive tax reforms must take country circumstances into account.

The study by Cobham and Janský (2018) examines the impacts of tax competition on the corporate income tax base. They revisit the influential study by Crivelli, de Mooij, and Keen (2016) using the GRD data and confirm that the results of the earlier study remain valid with the new data. On average, countries seem to lose less as a result of international spillovers in corporate taxation, but the difference in the extent of the loss between country groups is greater when compared with the original study: relative to their GDP, developing countries are more vulnerable to international tax competition than developed countries are.

The study by Hearson (2018) examines the determinants of having a tax treaty. In principle, tax treaties are meant to make sure foreign firms are not double taxed on the profits they earn abroad, thus making countries with treaties more attractive as investment destinations. However, a general concern is that the terms of the treaties are often not favourable at all to developing countries, with the implication that the base upon which they could potentially be taxed is made too narrow. Using data from the GRD together with information on the quantity and quality of tax treaties, Hearson finds that countries that are relatively more dependent on corporate income tax revenue negotiate treaties with higher withholding rates, but these treaties are no better in terms of other quality characteristics. Countries that have in general a greater tax capacity-measured by the tax to GDP ratio-are more likely to negotiate better clauses in areas that are less wellunderstood by non-specialists, including minimum levels of activity before foreign companies are liable for taxation-often referred to as permanent establishment-and provisions on particular types of income such as capital gains, pensions, and social security contributions. The overall conclusion of the paper is that developing countries should strive to renegotiate their tax treaties in order to broaden their tax bases.

The paper by Martorano (2018) analyses how the composition and type of taxes have influenced income distribution in Latin America. He finds that the increasing contribution of direct taxes since the early 2000s-relative to indirect taxes that were more dominant during the 1990s-led to more progressive tax systems in the Latin American region, which in turn contributed to a reduction in income inequality. However, given the high initial levels of inequality, and the low average tax revenue and limited capacity to tax top incomes, the redistributive effect of the tax system remains modest.

The third set of questions, on the relationship between democracy and tax revenue mobilisation (and the effect of political party system institutionalisation and political competition on the level of tax revenues), are examined in the studies by Armin von 
Schiller and Urbain Thierry Yogo and Martine Michele. The role of natural endowments in developing countries' revenue mobilisation efforts, the incentives that these resources generate for institutional building and the legacy of conflict (and how it affects fiscal capacity in fragile states in the context of Africa) are issues examined in the studies by Christian von Haldenwang and Maksym Ivanyna, and Vanessa van den Boogaard, et al., respectively.

More specifically, von Schiller (2018) examines the determinants of personal income tax in developing countries contexts, where reliance on this type of taxes is weak and often linked to limited bureaucratic capacity. Von Schiller finds evidence that stronger (democratic) political party systems are positively associated with personal income tax revenue, and this link is stronger in countries with weak bureaucratic capacity. There is quite a large degree of heterogeneity in these relationships, although no specific subsample is identified to clearly drive the results. The author concludes that for sustained success in revenue generation, the state must be credibly committed as regards linking taxes to the provision of public goods - an issue that we return to in the conclusion to this article-and that political parties have an important role to play in fostering this reciprocal relationship.

The study by Yogo and Ngo Njib (2018) empirically estimate the impact of political competition on tax collection in developing countries. The theoretical predictions regarding the influence of political competition on tax take are not clear cut. More political competition could mean, for instance, that voters have more freedom to vote for greater redistribution and because the median voter typically earns less than the mean income, this would tend to lead to increased revenues. Obviously, political preferences can vary in free democracies, and the overall impact is ambiguous. The overall results of the study are that, on average, greater political competition is associated with higher tax revenues. However, this relationship does not hold for countries that have adopted fiscal rules, whose direct impact on revenues tends to be positive, thus perhaps reducing the need for political processes to enforce tax collection.

Concerns about how terms-of-trade shocks affect government revenue capacity, and how countries with a high dependence on natural resource revenues perform in such contexts, are addressed in the paper by von Haldenwang and Ivanyna (2018). The authors find that revenue in resource-dependent countries is more vulnerable to external shocks, especially among richer countries, than non-resource dependent countries. Somewhat surprising is the finding that the difference between resource-rich and non-resource-rich countries is less pronounced in the group of poorer countries. The authors also find that the volatility of fiscal revenues declined in the 2000s relative to earlier decades, while political regime types do not seem to reduce the vulnerability of government revenues to external shocks.

Finally, the study by van den Boogaard, Prichard, Benson, and Milicic (2018) analyses the tax revenue mobilisation capacity of a number of conflict-affected nations since the 1980s. The authors first review different theoretical predictions about the impact of conflict on revenue collection. One hypothesis is that the government attempts to collect additional revenues before conflict to finance its war efforts, while adverse economic consequences can negatively influence available resources during conflicts. Based on a cross-country analysis and more in-depth country analysis, the authors find that overall, conflicts have a negative impact of revenue mobilisation. So, in contrast to European nations (Tilly, 1975), mobilisation for war, and the type of conflicts that have affected developing countries, do not appear to facilitate tax collection. 


\section{CONCLUDING REMARKS}

While progress in tax capacity in poor countries has been made, important challenges remain. As the studies in this special issue highlight, these challenges are linked to international aspects of taxation, countries' dependence on natural endowments, social structure and history, and the interplay between politics and revenues. Making further progress in tax capacity will depend on multiple factors, but especially on the social contract that states are able to build with tax payers, and where the willingness to pay taxes is increased if there is a reciprocal link with better quality services being provided by the state (Lenton, Masiye, \& Mosley, 2017).

The studies in this special issue have used the GRD dataset as the primary data source and consequently adopt cross-country analyses and economic and political economy analytical frameworks. Concerns about the microeconomics of taxation, incumbent behaviour and the politics of tax policy in specific country-level contexts, as well as other areas identified by individual papers in this special issue, represent important areas for future research.

\section{REFERENCES}

Acemoglu D, Robinson JA. 2012. Why Nations Fail: The Origins of Power, Prosperity, and Poverty. Crown Business: New York.

Addison T. (2015). Thirty Years in Africa's Development: From Structural Adjustment to Structural Transformation. WIDER Working Paper 2015/119. UNU-WIDER. Helsinki.

Addison T, Chowdhury AR, Murshed SM. 2004. The Fiscal Dimensions of Conflict and Reconstruction. In Fiscal Policy for Development: Poverty, Reconstruction and Growth, Addison T, Roe A (eds). Palgrave Macmillan for UNU-WIDER: Basingstoke; 260-273.

Addison T, Hansen H, Tarp F (Eds). 2004. Debt Relief for Poor Countries. Palgrave Macmillan: Basingstoke.

Addison T, Niño-Zarazúa M, Tarp F. 2015. Aid, Social Policy and Development. Journal of International Development 27(8): 1351-1365. https://doi.org/10.1002/jid.3187

Alesina A, Campante FR, Tabellini G. 2008. Why is Fiscal Policy Often Procyclical? Journal of the European Economic Association 6(5): 1006-1036. https://doi.org/10.1162/ JEEA.2008.6.5.1006

Alesina A, Giuliano P. 2011. Chapter 4-preferences for redistribution. In Handbook of Social Economics, Benhabib J, Bisin A, Jackson MO (eds), 1: North-Holland; 93-131.

Alesina A, Ardagna S. 2010. 2 Large Changes in Fiscal Policy: Taxes Versus Spending. Tax Policy and the Economy 24(1): 35-68. https://doi.org/10.1086/649828

Atkinson AB, Stiglitz JE. 1972. The Structure of Indirect Taxation and Economic Efficiency. Journal of Public Economics 1(1): 97-119. https://doi.org/10.1016/0047-2727(72)90021-7

Atkinson AB, Stiglitz JE. 1976. The Design of Tax Structure: Direct Versus Indirect Taxation. Journal of Public Economics 6(1): 55-75. https://doi.org/10.1016/0047-2727(76)90041-4

Baldacci E, Hillman AL, Kojo NC. 2004. Growth, Governance, and Fiscal Policy Transmission Channels in Low-Income Countries. European Journal of Political Economy 20(3): 517-549. https://doi.org/10.1016/j.ejpoleco.2003.12.002

Baskaran T, Bigsten A. 2013. Fiscal Capacity and the Quality of Government in Sub-Saharan Africa. World Development 45: 92-107. https://doi.org/10.1016/j.worlddev.2012.09.018 
Benedek D, Crivelli E, Gupta S, Muthoora P. 2014. Foreign Aid and Revenue: Still a Crowding-Out Effect? FinanzArchiv: Public Finance Analysis 70(1): 67-96. https://doi.org/10.1628/ $001522114 X 679156$

Besley T, Persson T. 2011. Pillars of Prosperity. The Political Economics of Development Clusters. Princeton University Press: Princeton.

Bleaney M, Gemmell N, Kneller R. 2001. Testing the Endogenous Growth Model: Public Expenditure, Taxation, and Growth over the Long Run. Canadian Journal of Economics/Revue canadienne d'économique 34(1): 36-57. https://doi.org/10.1111/0008-4085.00061

Caselli F, Cunningham T. 2009. Leader Behaviour and the Natural Resource Curse. Oxford Economic Papers 61(4): 628-650. https://doi.org/10.1093/oep/gpp023

Cobham A, Janský P. 2018. Global Distribution of Revenue Loss from Corporate Tax Avoidance: Re-Estimation and Country Results. Journal of International Development 30(2): 206-232.

Crivelli E, de Mooij R, Keen M. 2016. Base Erosion, Profit Shifting and Developing Countries. FinanzArchiv: Public Finance Analysis 72(3): 268-301. https://doi.org/10.1628/ 001522116 X14646834385460

Daniel P, Keen M, Świstak A, Thuronyi V (Eds). 2017. International Taxation and the Extractives Industries. Routledge: London.

Deaton A. 1977. Equity, Efficiency, and the Structure of Indirect Taxation. Journal of Public Economics 8(3): 299-312. https://doi.org/10.1016/0047-2727(77)90003-2

Devereux MB, Wen J-F. 1998. Political Instability, Capital Taxation, and Growth. European Economic Review 42(9): 1635-1651. https://doi.org/10.1016/S0014-2921(97)00100-1

Dhami S. 2003. The Political Economy of Redistribution Under Asymmetric Information. Journal of Public Economics 87(9): 2069-2103. https://doi.org/10.1016/S0047-2727(02)00037-3

Emmens M, Kephart B. 2005. Dividend Taxation and Corporate Governance. The Journal of Economic Perspectives 19(3): 163-180. https://doi.org/10.1257/089533005774357752

Feldstein MS. 1972. Equity and Efficiency in Public Sector Pricing: The Optimal Two-Part Tariff. The Quarterly Journal of Economics 86(2): 176-187. https://doi.org/10.2307/1880558

Ganghof S, Genschel P. 2008. Taxation and Democracy in the EU. Journal of European Public Policy 15(1): 58-77. https://doi.org/10.1080/13501760701702199

Gordon RH. 1983. An Optimal Taxation Approach to Fiscal Federalism. The Quarterly Journal of Economics 98(4): 567-586. https://doi.org/10.2307/1881778

Grown C, Addison T, Tarp F. 2016. Aid for Gender Equality and Development: Lessons and Challenges. Journal of International Development 28(3): 311-319.

Gupta S, Tareq S, Clements B, Segura-Ubiergo A, Bhattacharya R. 2009. Post-Conflict Countries: Strategy for Rebuilding Fiscal Institutions. In Making Peace Work: The Challenges of Social and Economic Reconstruction, Addison T, Brück T (eds). Palgrave Macmillan: Basingstoke; 175-199.

Haber S, Menaldo V. 2011. Do Natural Resources Fuel Authoritarianism? A Reappraisal of the Resource Curse. American Political Science Review 105(1): 1-26. https://doi.org/10.1017/ S0003055410000584

Hearson M. 2018. When Do Developing Countries Negotiate Away Their Corporate Tax Base? Journal of International Development 30(2): 233-255.

Herb M. 2005. No Representation Without Taxation? Rents, Development, and Democracy. Comparative Politics 37(3): 297-316. https://doi.org/10.2307/20072891

Jaimovich N, Rebelo S. 2017. Nonlinear Effects of Taxation on Growth. Journal of Political Economy 125(1): 265-291. https://doi.org/10.1086/689607

Keen M, Slemrod J. 2017. Optimal Tax Administration, IMF Working Paper WP/17/18. International Monetary Fund: Washington, DC. 
Lenton P, Masiye M, Mosley P. 2017. Taxpayer's Dilemma: How Can 'Fiscal Contracts' Work in Developing Countries? Sheffield Economics Research Paper Series No. 2017004. Department of Economics, Sheffield University: Sheffield.

Marjit S, Mukherjee V, Kolmar M. 2006. Poverty, Taxation and Governance. The Journal of International Trade \& Economic Development 15(3): 325-333. https://doi.org/10.1080/ 09638190600871636

Martorano B. 2018. Taxation and Inequality in Developing Countries: Lessons from the Recent Experience of Latin America. Journal of International Development 30(2): 256-273.

McNabb K. 2018. Tax Structures and Economic Growth: New Evidence from the Government Revenue Dataset. Journal of International Development 30(2): 173-205.

Moore M. 2007. How Does Taxation Affect the Quality of Governance? IDS working papers 280. IDS: Sussex.

Mosley P. 2014. The Politics of What Works for the Poor in Public Expenditure and Taxation. In The Politics of Inclusive Development: Interrogating the Evidence, Hickey S, Sen K, Bukenya B (eds). Oxford University Press: Oxford; 60-85.

Mosley P. 2017. Fiscal Policy and the Natural Resources Curse: How to Escape from the Poverty Trap. Routledge: London.

Muinelo-Gallo L, Roca-Sagalés O. 2013. Joint Determinants of Fiscal Policy, Income Inequality and Economic Growth. Economic Modelling 30: 814-824. https://doi.org/10.1016/j. econmod.2012.11.009

Mutascu M. 2011. Taxation and Democracy. Journal of Economic Policy Reform 14(4): 343-348. https://doi.org/10.1080/17487870.2011.635037

Persson T, Tabellini G. 1994. Representative Democracy and Capital Taxation. Journal of Public Economics 55(1): 53-70. https://doi.org/10.1016/0047-2727(94)90080-9

Prichard W. 2016. Reassessing Tax and Development Research: A New Dataset, New Findings, and Lessons for Research. World Development 80: 48-60. https://doi.org/10.1016/j.worlddev. 2015.11.017

Sandmo A. 2005. The Theory of Tax Evasion: A Retrospective View. National Tax Journal 58(4): 643-663.

Scully GW. 2003. Optimal Taxation, Economic Growth and Income Inequality. Public Choice 115(3): 299-312. https://doi.org/10.1023/a:1024223916710

Shavell S. 1981. A Note of Efficiency vs. Distributional Equity in Legal Rulemaking: Should Distributional Equity Matter Given Optimal Income Taxation? The American Economic Review 71(2): 414-418.

Slemrod J. 2007. Cheating Ourselves: The Economics of Tax Evasion. The Journal of Economic Perspectives 21(1): 25-48. https://doi.org/10.1257/089533007780095529

Slemrod J, Yitzhaki S. 2002. Chapter 22-Tax Avoidance, Evasion, and Administration. In Handbook of Public Economics, Alan JA, Martin F (eds), 3. Elsevier; 1423-1470.

Stewart F. 1996. Adjustment and Poverty: Options and Choices. Routledge: London.

Tilly C (Ed). 1975. The Formation of National States in Western Europe. Princeton University Press: Princeton.

United Nations. (2015). Addis Ababa Action Agenda of the Third International Conference on Financing for Development. Retrieved from New York:

van den Boogaard V, Prichard W, Benson M, Milicic N. 2018. Tax Revenue Mobilization in Conflict-Affected Developing Countries. Journal of International Development 30(2): 345-364. von Haldenwang C, Ivanyna M. 2018. Does the Political Resource Curse Affect Public Finance? The Vulnerability of Tax Revenue in Resource-Dependent Countries Journal of International Development 30(2): 323-344. 
von Schiller A. 2018. Party System Institutionalisation and Reliance on Personal Income Taxation in Developing Countries. Journal of International Development 30(2): 274-301.

Woo J. 2011. Growth, Income Distribution, and Fiscal Policy Volatility. Journal of Development Economics 96(2): 289-313. https://doi.org/10.1016/j.jdeveco.2010.10.002

Yakita A. 2003. Taxation and Growth with Overlapping Generations. Journal of Public Economics 87(3-4): 467-487. https://doi.org/10.1016/S0047-2727(01)00083-4

Yogo UT, Ngo Njib M. 2018. Political Competition and Tax Revenues in Developing Countries. Journal of International Development 30(2): 302-322. 